\title{
ESSKA from Berlin 1984 to Barcelona 2016: "from a resident to a President"
}

\author{
Matteo Denti
}

Published online: 13 April 2014

(c) Springer-Verlag Berlin Heidelberg 2014

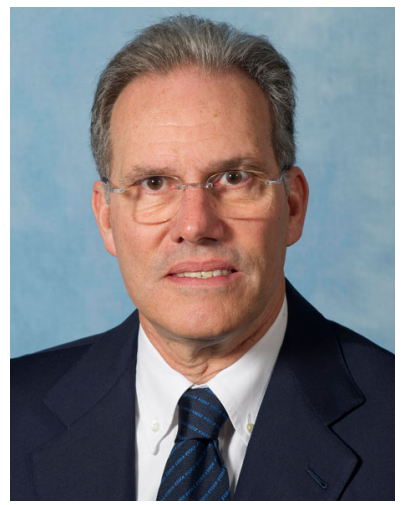

In 1984, I was a young resident, but even then, I was interested in knee surgery, sports traumatology, and arthroscopic surgery as a result of having attended the first courses in this new discipline, using, what seem to us now, rudimentary instruments.

I went to Berlin, to the first ESKKA meeting, as it was called then. It was Berlin divided by the Berlin wall, and so a city full of contradictions, a fascinating city, made all the more so because I was hoping to meet for the first time the "legendary" names in orthopaedics, people I had only read about in books and scientific journals. You can imagine my thrill when I was able to see pioneers in the field, such as

Dr. Matteo Denti was a former President of Società Italiana Ginocchio Artroscopia Sport Cartilagine Tecnologie Ortopediche (SIGASCOT).

\section{Denti ( $\square)$}

European Society of Sports Traumatology, Knee Surgery and Arthroscopy (ESSKA), Luxemburg, Luxemburg

e-mail: matteo@denti.ch.it

Albert Trillat, who, when asking a question, would say his name followed by "France," his country, and it was all curious and exciting for a young resident.

At that time, few people knew each other in person, people were known only by their reputation, but an important nucleus was formed, which would result in the birth of something new, just like the "new" Berlin. A vision arose of a scientific community without frontiers, and the idea of working together for a common good was born in this city on the brink of change.

My ideas were still confused. Torn between the old-style surgery and the new "futuristic" ideas of arthroscopic surgery, and of prosthetic joints. I have always had a European outlook, transcending national boundaries, I looked outwards from my own country to a Europe that I saw as common "country" for all of us, I saw it as an extension of my country.

So when Ejnar Eriksson used to say, at times in an arrogant tone, (but only to goad his colleagues from the other side of the ocean), "this, we discussed then achieve first in Europe," I liked what he said, I felt proud, I felt European. We were building our knowledge, our identity, a certain collective consciousness was taking place.

It is in this spirit that ESSKA began to take form and to become a reality. We have two godfathers, Ejnar Eriksson and Werner Muller, to which we owe so much. Two years later in Basel, another idea had already taken shape, the idea of creating a travelling fellowship with the Americans. Werner Muller together with John Feagin had this brilliant idea, and without delay three fellows and a godfather had left for the USA the year before, and that year in Basel, the first American fellows were hosted.

When in Basel, I had been invited to dine, with Carlo Fabbriciani, perhaps because of the brotherly relationship we had. 
Carlo had, the year before, been one of the first fellows to go to the USA. We went to the same restaurant where the fantastic idea of uniting, with the same dignity, Europe and the USA had been born. In that restaurant I too formed an idea, a desire to work hard to have the same chance, and the dream was to be an ESSKA travelling fellow. This dream was realised in 1989, and it was the most wonderful and exciting experience in my orthopaedic career.

Basel was a great success, as were the congresses that followed (Amsterdam and Stockholm). I never missed an ESSKA Congress in my life, and in Palma de Mallorca in 1992, I was honoured to receive, thanks to a research done with Alfredo Schiavone Panni, the Theo Van Rens prize for the best scientific paper of the congress. Our research was published in the first number of the KSSTA journal, which a few months later in 1993 saw its first Christmas, and many more have followed, thanks to its insightful founder Ejnar Eriksson. Now, we too had our scientific journal that over the years has grown form 66 pages up to almost 3,000 pages a year, and it has grown not only in pages but also in international reputation.

ESSKA too was growing under the guidance of active presidents and visionaries who together with their board members were always full of inspiration, providing new and improved training methods for European surgeons.

And in this way, in Berlin 1994 and then Budapest, Nice, London, Rome, Athens, Innsbruck, Porto, Oslo, Geneva, and right up to Amsterdam in 2014, one success has led to another in terms of the number of ESSKA participants and scientific value. They were offered a vast array of opportunities such as fellowship, travelling fellowship, grants, etc., aimed mainly at young members, but senior members could take advantage of the ESSKA too (Alwin Jager Fellowship).

ESSKA has become more organised and more structured, with sections and committees and an efficient and professional head office in Luxembourg.

The duties of the ESSKA president and the board have become over the years always more demanding when compared to the first "armature-like" efforts of all those years ago in 1983.

In 2013, the ESSKA Foundation was formed with the aim of promoting scientific research and education in our field, and this is the ESSKA that we know today, with its honourable mission:

"Bringing together orthopaedic surgeons, clinicians and scientists in Europe, ESSKA raises the level of care in the field of orthopaedic sports medicine and degenerative joint diseases to improve musculoskeletal function and quality of life of patients.

ESSKA supports education and research and aims to improve cooperation among its members, national and international societies in the field of prevention and surgery with special emphasis on arthroscopy".

We are proud to have over 2,600 members in 85 countries and in all 5 continents, we have 23 affiliated scientific societies from many different nations in Europe and the new ESSKA Foundation.

We can now boast over 70 fellowships.

Our Members have access to:

- A vast array of scientific publications and training DVD's;

- The ESSKA Academy, an online educational platform;

- Above all, our "crowning jewel" the KSSTA Journal, which has, in the last few years, become more and more important, under the guidance and tireless work of the Editor in Chief, Jon Karlsson, and his board, who are able to give it importance and an ever growing impact factor.

I feel great pride when I see KSSTA quoted in almost all scientific publications and congresses around the world.

The KSSTA team is truly phenomenal thanks to its Assistant Editor, senior Editor, 9 Associate Editors, and an incredible Editorial Board.

In terms of "world ranking" we are, thanks to their efforts, in "pole position"! It is our hope that we will have even more world acclaim from the scientific community with our new "creation," the on-line JEO, Journal of Experimental Orthopaedics, with its Editor Henning Madry; it has our full support and we share the hope that it will enjoy the success that KSSTA has. KSSTA and JEO provide a valuable link from our past to our scientific future. KSSTA, JEO, and ESSKA Academy work closely to add value to scientific knowledge in the field of knee surgery, sport traumatology, and arthroscopy, and in this way, knowledge and learning can be shared.

We have come a long way thanks to Ejnar and Werner. I too have come a long way, from resident at the ESKA Congress in Berlin 1984. Now, I am the proud president of ESSKA (from 2014 until Barcelona 2016).

ESSKA, my home, my life coach. I hope to be equal to this important task.

Matteo Denti

President of ESSKA 2014-2016 